\title{
Optimization of gallic acid-loaded transfersomes using a Box-Behnken factorial design
}

\author{
Otimização de transferossomas para encapsular ácido gálico através de um desenho fatorial do \\ tipo Box-Behnken
}

\section{Catarina Pereira-Leite ${ }^{1,2}$, Carolina Ventura ${ }^{3}$}

\author{
${ }^{1}$ CBIOS - Universidade Lusófona's Research Center for Biosciences \& Health Technologies, Av Campo Grande 376, 1749-024 \\ Lisboa, Portugal \\ ${ }^{2}$ LAQV, REQUIMTE, Departamento de Ciências Químicas, Faculdade de Farmácia, Universidade do Porto, Rua de Jorge \\ Viterbo Ferreira 228, 4050-313 Porto, Portugal \\ ${ }^{3}$ School of Sciences and Health Technologies, Universidade Lusófona de Humanidades e Tecnologias, Av. Campo Grande 376, \\ 1749-024 Lisboa, Portugal \\ *corresponding author: catarina.leite@ulusofona.pt
}

\begin{abstract}
The pleiotropic activities of gallic acid have triggered the interest of researchers in the improvement of its poor bioavailability, such that this phenolic compound can be used for prophylactic and therapeutic purposes. At the same time, transfersomes have been reported to be valuable nanodelivery systems to boost the transdermal delivery of bioactive compounds. Thus, this study aims at optimizing a transfersomal formulation for the transdermal delivery of gallic acid using a Box-Behnken factorial design. This experimental design was successfully implemented and validated, yielding an optimized formulation with the desirable properties in terms of size, polydispersity index and loading capacity. Overall, this study opens up the possibility of efficiently delivering gallic acid to the deeper layers of skin in pharmaceutical and cosmetic formulations.
\end{abstract}

Keywords: vesicular delivery systems, nanotechnology, phytochemicals, Box-Behnken

\section{Resumo}

As atividades pleiotrópicas do ácido gálico têm despertado o interesse dos investigadores no sentido de melhorar a sua baixa biodisponibilidade, de modo que este composto fenólico possa ser usado para fins profiláticos e terapêuticos. Simultaneamente, tem sido demonstrado que os transferossomas são nanossistemas valiosos para melhorar a veiculação transdérmica de compostos bioativos. Assim, este estudo tem como objetivo otimizar uma formulação transferossomal para a veiculação transdérmica de ácido gálico utilizando um desenho fatorial do tipo Box-Behnken. Este desenho experimental foi implementado e validado com sucesso, dando origem a uma formulação otimizada com as propriedades desejáveis em termos de tamanho, índice de polidispersão e capacidade de carga. No geral, este estudo poderá ser o primeiro passo quanto à veiculação eficiente de ácido gálico até às camadas mais profundas da pele em formulações farmacêuticas e cosméticas.

Palavras-chave: Sistemas de veiculação vesiculares, nanotecnologia, fitoquímica, desenho fatorial Box-Behnken 


\section{Introduction}

Transfersomes are ultraflexible vesicles made of phospholipids and an edge activator (EA) for transdermal delivery of hydrophobic and hydrophilic molecules $(1,2)$. The presence of the edge activators in the phospholipid bilayer results in a higher curvature radius, increasing the deformability of the vesicle (2). In contrast to other vesicular systems, namely liposomes and niosomes, transfersomes are able to reach deeper skin layers by squeezing through channels of the stratum corneum $(2,3)$. Both surfactants and bile salts have been successfully used as edge activators up to $25 \%(\mathrm{w} / \mathrm{w})$ without disrupting the vesicles $(2,4-7)$. Transfersomes also seem to be more advantageous as nanodelivery systems than liposomes and niosomes, as they exhibit better colloidal stability, improving the shelf-life of products (2). In the last 30 years of transfersomal research, these vesicular systems have been studied for the dermal/transdermal delivery of anti-diabetic, anti-inflammatory, anti-hypertensive, immunologic, anti-cancer, anti-depressive compounds (3). In fact, one transfersomal product was previously commercialized in Switzerland for the treatment of osteoarthritis (Diractin ${ }^{\circledR}$ from IDEAAG), but it was later withdrawn from the market, and the company withdrew its marketing authorization application submitted to the European Medicines Agency in 2008 (8). The principal reason underlying this withdrawal was its lack of efficacy compared with placebo in reducing pain levels in osteoarthritic patients. Thus, research in this field has continued in effort to efficiently improve such transdermal therapy.

From the beginning of the $21^{\text {st }}$ century, the pharmaceutical development of medicines has been improved in terms of quality and reduced costs by the implementation of quality-by-design (QbD). This concept consists of identifying the critical quality attributes, the critical material attributes, and the critical process parameters to control the development process in various steps to ultimately obtain a product with predefined specifications $(2,9)$. This approach is highly advantageous to reduce the number of experiments needed to develop a medicine, reducing the manufacturing costs, which is particularly relevant for nanomedicines due to their complex production methods and material prices (2). In this sense, the implementation of QbD may improve the probability of innovative nanoformulations, including transfersomes, to reach the market in the upcoming years.

\section{Introdução}

Os transferossomas são vesículas ultraflexíveis constituídas por fosfolípidos e um ativador de superfície (EA) desenvolvidos para veiculação transdérmica de compostos hidrofóbicos e hidrofílicos $(1,2)$. A presença dos ativadores de superfície na bicamada fosfolipídica resulta num raio de curvatura mais elevado, aumentando a deformabilidade da vesícula (2). Ao contrário de outros sistemas vesiculares, como os lipossomas e os niossomas, os transferossomas são capazes de atingir camadas mais profundas da pele ao penetrarem através dos canais do estrato córneo (2, 3). Tanto surfactantes, quanto sais biliares têm sido utilizados com sucesso como ativadores de superfície até $25 \%(\mathrm{~m} / \mathrm{m})$ sem destruir as vesículas $(2,4-7)$. Outra vantagem dos transferossomas em relação aos lipossomas e aos niossomas é o facto de apresentarem melhor estabilidade coloidal, prolongando o prazo de validade dos produtos (2). Nos últimos 30 anos, os transferossomas têm vindo a ser estudados para a administração dérmica e transdérmica de compostos antidiabéticos, anti-inflamatórios, anti-hipertensivos, imunológicos, anticancerígenos e antidepressivos (3). De facto, uma formulação transferossomal já foi comercializada na Suíça para o tratamento da osteoartrite (Diractin $^{\circledR}$ da IDEA AG), mas esta foi, entretanto, retirada do mercado, assim como foi retirado o pedido de autorização de introdução no mercado, anteriormente apresentado à Agência Europeia do Medicamento, em 2008 (8). A principal razão subjacente a esta retirada foi a sua falta de eficácia em comparação com o placebo na redução dos níveis de dor em pacientes com osteoartrite. Assim, a investigação nesta área continuou no sentido de melhorar de forma eficiente a terapia transdérmica.

Desde o início do século XXI, o desenvolvimento farmacêutico de medicamentos tem sido aprimorado em termos de qualidade e redução de custos com a implementação do Quality-by-Design (QbD). Este conceito consiste em identificar os atributos críticos de qualidade, os atributos críticos de materiais e os parâmetros críticos de processo para controlar o processo de desenvolvimento em várias etapas para, em última instância, se obter um produto com as especificações predefinidas (2,9). Essa abordagem é altamente vantajosa para reduzir o número de experiências necessárias para o desenvolvimento de um medicamento, diminuindo os custos de fabrico, o que é particularmente relevante para nanossistemas devido aos seus métodos de produção complexos e aos preços dos materiais (2). Neste sentido, a implementação do QbD pode aumentar a probabilidade de nanoformulações 
Gallic acid is an abundant phenolic acid in various plants with potent free radical scavenging and antioxidant activity, and as such, gallic acid and derivatives are useful in the food industry as preservative agents (10). In fact, gallic acid has been shown to display pleiotropic activities, ranging from cell protection from oxidative stress to neuroprotective, cardioprotective, antidiabetic, anticarcinogenic, anti-inflammatory and antimicrobial effects $(10,11)$. Thus, this phytochemical is an excellent candidate for both pharmacological and cosmetic applications $(11,12)$. The main drawbacks of gallic acid administration are its poor water solubility and low systemic bioavailability (12), which has triggered the scientific community to make use of nanotechnology to improve the bioavailability of gallic acid (13-17).

In this context, this work aims at optimizing a gallic acid-loaded transfersomal formulation for transdermal applications. A QbD approach was considered to optimize the formulation, making use of a BoxBehnken factorial design (BBD). BBD is a multivariate optimization strategy that allows the simultaneous evaluation of the effect of the selected factors and their interactions on the selected responses (18). Among response surface designs, BBD was shown to be one of the most efficient designs, requiring a low number of experiments, allowing the reduction of reagent consumption, and avoiding the time-consuming testing of univariate optimization strategies $(18,19)$. In this study, a BBD was successfully implemented to optimize a gallic acid-loaded vesicular delivery system for transdermal applications.

\section{Materials and Methods}

\section{Materials}

Gallic acid monohydrate, potassium chloride, potassium phosphate monobasic, and Tween ${ }^{\circledR} 80$ were purchased from Sigma-Aldrich (Saint Louis, MO, USA). Lecithin of soya was purchased from VWR International bvba (Leuven, Belgium). Disodium hydrogen phosphate dihydrate and chloroform were obtained from Scharlab S.L. (Sentmenat, Spain). Sodium chloride was obtained from José M. Vaz Pereira S.A. (Benavente, Portugal). Sephadex ${ }^{\mathrm{TM}}$ G-25 medium was purchased from GE inovadoras, incluindo transferossomas, chegarem ao mercado nos próximos anos.

O ácido gálico é um ácido fenólico abundante em várias plantas com uma potente atividade antioxidante, pelo que o ácido gálico e seus derivados são úteis na indústria dos alimentos como agentes conservantes (10). De facto, o ácido gálico é um agente pleiotrópico, variando a sua atividade desde a proteção celular em resposta ao stress oxidativo aos seus efeitos neuroprotetores, cardioprotetores, antidiabéticos, anticarcerígenos, anti-inflamatórios e antimicrobianos $(10,11)$. Assim, este fitoquímico é um excelente candidato para aplicações farmacológicas e cosméticas $(11,12)$. As principais desvantagens da administração do ácido gálico são a baixa solubilidade aquosa e a sua baixa biodisponibilidade sistémica (12), pelo que a comunidade científica tem vindo a recorrer à nanotecnologia para melhorar a biodisponibilidade do ácido gálico (13-17).

Neste contexto, este trabalho tem como objetivo a otimização de uma formulação transferossomal para veicular o ácido gálico por via transdérmica. A otimização da formulação foi baseada numa estratégia de $\mathrm{QbD}$, utilizando um desenho fatorial do tipo BoxBehnken (BBD). O BBD é uma estratégia de otimização multivariada que permite a avaliação simultânea do efeito dos fatores selecionados e das suas interações nas respostas selecionadas (18). Entre os desenhos de superfície de resposta, o BBD mostrou-se um dos mais eficientes, exigindo um baixo número de experiências, permitindo assim a redução do consumo de reagentes e evitando a duração prolongada das estratégias de otimização univariadas $(18,19)$. Neste estudo, um BBD foi implementado com sucesso para otimizar um sistema transferossomal para veicular o ácido gálico por via transdérmica.

\section{Material e Métodos}

\section{Materiais}

O ácido gálico mono-hidratado, o cloreto de potássio, o fosfato de potássio monobásico e Tween ${ }^{\circledR} 80$ foram adquiridos na Sigma-Aldrich (Saint Louis, MO, EUA). A lecitina de soja foi adquirida na VWR International bvba (Leuven, Bélgica). O hidrogenofosfato dissódio di-hidratado e o clorofórmio foram obtidos na Scharlab S.L. (Sentmenat, Espanha). O cloreto de sódio foi obtido de José M. Vaz Pereira S.A. (Benavente, Portugal). O Sephadex ${ }^{\mathrm{TM}}$ G-25 médio foi adquirido 
Healthcare Bio-sciences AB (Uppsala, Sweden). Methanol was obtained from Carlo Erba Reagenti SpA (Rodano, Italy). All reagents were used without further purification.

Phosphate buffered saline (PBS, pH 7.4) was prepared by dissolving sodium chloride $(137 \mathrm{mM})$, potassium chloride $(2.7 \mathrm{mM})$, disodium hydrogen phosphate dihydrate $(10 \mathrm{mM})$ and potassium phosphate monobasic $(1.8 \mathrm{mM})$ in distilled water. The $\mathrm{pH}$ was adjusted with $\mathrm{NaOH}$ or $\mathrm{HCl}$ solutions (1 M).

\section{Preparation of transfersomes}

Transfersomes were produced by the thin-film hydration method followed by sonication. Briefly, lecithin and Tween $^{\circledR} 80$ were dissolved in chloroform:methanol $(3: 1, v / v)$. EA:lipid films were produced by evaporating the organic solvents in a rotary evaporator at $40^{\circ} \mathrm{C}$ for 45 min and leaving under vacuum to remove traces of organic solvents. The films were hydrated with a gallic acid $(0.75 \% \mathrm{w} / \mathrm{v})$ PBS buffered solution, vigorously vortexed, and sonicated at 50\% amplitude using a Q125 Sonicator from QSonica Sonicators (Newtown, CT, USA).

\section{Experimental design}

The optimization of the gallic acid-loaded transfersomal formulation was based on a 15-run, 3-factor, 3-level Box-Behnken factorial design (BBD). The lipid concentration $\left(\mathrm{X}_{1}\right)$, the EA:lipid ratio $\left(\mathrm{X}_{2}\right)$ and the sonication time $\left(\mathrm{X}_{3}\right)$ were defined as independent variables, also called factors, and three levels of each independent variable were tested (Table 1), according to preliminary results and literature research. The size $\left(\mathrm{Y}_{1}\right)$, the polydispersity index $\left(\mathrm{Y}_{2}\right)$ and the loading capacity $\left(\mathrm{Y}_{3}\right)$ were defined as dependent variables, also called responses, and the corresponding desirable criteria were defined for each dependent variable (Table 1). Data were analyzed in STATISTICA software (Statsoft, Inc., Tulsa, OK, USA), as previously reported $(20,21)$, providing the optimum values of the factors based on the desirable criteria for the responses. To validate the experimental design, three replicates of the optimized formulation were produced and characterized to compare the obtained values for the dependent variables with the theoretical values predicted by the BBD. da GE Healthcare Bio-sciences AB (Uppsala, Suécia). O metanol foi obtido da Carlo Erba Reagenti SpA (Rodano, Itália). Todos os reagentes foram utilizados sem purificação adicional.

O tampão fosfato (PBS, $\mathrm{pH} 7,4)$ foi preparado através da dissolução do cloreto de sódio $(137 \mathrm{mM})$, do cloreto de potássio $(2,7 \mathrm{mM})$, do hidrogenofosfato dissódico dihidratado $(10 \mathrm{mM})$ e do fosfato de potássio monobásico $(1,8 \mathrm{mM})$ em água destilada. $\mathrm{O} \mathrm{pH}$ foi ajustado com uma solução de $\mathrm{NaOH}$ ou $\mathrm{HCl}$ (1 M).

\section{Preparação dos transferossomas}

Os transferossomas foram produzidos pelo método de hidratação do filme lipídico seguido de sonicação. A lecitina e o Tween $^{\circledR} 80$ foram dissolvidos em clorofórmio:metanol $(3: 1, \mathrm{v} / \mathrm{v})$. Os filmes de EA:lípido foram produzidos através da evaporação dos solventes orgânicos num evaporador rotativo a $40{ }^{\circ} \mathrm{C}$ durante 45 min. Os vestígios de solventes orgânicos foram removidos sob vácuo. De seguida, os filmes foram hidratados com uma solução tamponada de ácido gálico $(0,75 \% \mathrm{~m} / \mathrm{v})$, sendo vigorosamente agitados e posteriormente sonicados a $50 \%$ de amplitude usando o sonicador Q125 da QSonica Sonicators (Newtown, CT, EUA).

\section{Desenho experimental}

A otimização da formulação transferossomal para veicular ácido gálico foi baseada num desenho fatorial do tipo Box-Behnken (BBD) considerando 15 séries, três fatores e três níveis. A concentração lipídica $\left(\mathrm{X}_{1}\right)$, a razão EA:lípido $\left(\mathrm{X}_{2}\right)$ e o tempo de sonicação $\left(\mathrm{X}_{3}\right)$ foram definidos como variáveis independentes, também denominadas fatores. Foram testados três níveis de cada variável independente (Tabela 1), tendo em conta os resultados preliminares e a literatura. $\mathrm{O}$ tamanho $\left(\mathrm{Y}_{1}\right)$, o índice de polidispersão $\left(\mathrm{Y}_{2}\right)$ e a capacidade de carga $\left(\mathrm{Y}_{3}\right)$ foram definidos como variáveis dependentes, também denominadas de respostas, e os critérios desejáveis foram definidos para cada variável dependente (Tabela 1). Os dados foram analisados no software STATISTICA (Statsoft, Inc., Tulsa, OK, EUA), conforme relatado anteriormente $(20,21)$, de forma a se obterem os valores ótimos dos fatores com base nos critérios desejáveis para as respostas. Para validar o desenho experimental, três réplicas da formulação otimizada foram produzidas e caraterizadas para comparar os valores obtidos quanto às variáveis dependentes com os valores teóricos previstos pelo BBD. 


\section{Characterization of transfersomes}

The produced transfersomes were characterized in terms of size and polydispersity index (PDI) using Delsa $^{\mathrm{TM}}$ Nano $\mathrm{C}$ from Beckman Coulter, Inc. (Brea, CA, USA). Triplicates were analyzed at $23 \pm 2{ }^{\circ} \mathrm{C}$ after diluting the samples $(20-25 \mathrm{x})$ with distilled water.

Loading capacity (LC) was determined after separating the non-loaded fraction of gallic acid by size exclusion chromatography, using Sephadex ${ }^{\mathrm{TM}}$ G-25 medium as stationary phase and PBS buffer as mobile phase in the dark. An aliquot of the transfersomal formulation $(500 \mu \mathrm{l})$ was eluted to separate the gallic acid-loaded fraction (peak at $\sim 12 \mathrm{~min}$ ) from the non-loaded fraction (peak at $\sim 45 \mathrm{~min}$ ), which were efficiently separated by an interval of at least $15 \mathrm{~min}$. After visually ensuring that the gallic acid-loaded fraction was eluted, the non-loaded fraction of gallic acid was pooled and the calibration curve method at $259 \mathrm{~nm}$ was used to determine the phytochemical concentration using UV spectrophotometry (Evolution ${ }^{\circledR} 300$ spectrophotometer, Thermo Scientific, Hertfordshire, England)). The same calibration curve method was used to determine the total concentration of gallic acid added to produce transfersomes. Finally, LC was calculated as follows:

$$
L C=\frac{C_{T}-C_{N L F}}{C_{L}} \quad \text { Eq. } 1
$$

where $\mathrm{C}_{\mathrm{T}}$ stands for the total concentration added of gallic acid, $\mathrm{C}_{\mathrm{NLF}}$ for the gallic acid concentration in the non-loaded fraction and $\mathrm{C}_{\mathrm{L}}$ for the total concentration of lipid, calculated from the amount initially weighed to produce transfersomes.

\section{Results}

The optimization of the gallic acid-loaded transfersomal formulation was based on a 15-run, 3-factor, 3-level BoxBehnken factorial design (BBD). Fifteen formulations were suggested by the STATISTICA software according to the levels chosen for the independent variables (Table 1). It is noteworthy that the independent variables were chosen based on previous data reported in the literature $(4,5)$, particularly in the case of the levels of the chosen lipid (soy lecithin) and edge activator (Tween ${ }^{\circledR} 80$ ), which have been widely used to

\section{Caraterização dos transferossomas}

Os transferomas produzidos foram caraterizados em termos de tamanho e índice de polidispersão (PDI) usando o equipamento Delsa ${ }^{\mathrm{TM}}$ Nano $\mathrm{C}$ da Beckman Coulter, Inc. (Brea, CA, EUA). Cada formulação foi analisada em triplicado a $23 \pm 2{ }^{\circ} \mathrm{C}$ após diluição com água destilada (20-25x).

A capacidade de carga (LC) foi determinada após a separação da fração livre de ácido gálico da fração encapsulada por cromatografia de exclusão por tamanho, usando o Sephadex ${ }^{\mathrm{TM}}$ G-25 como fase estacionária e o tampão PBS como fase móvel no escuro. Uma alíquota da formulação transferossomal $(500 \mu 1)$ foi eluída para separar a fração encapsulada de ácido gálico (pico aos $~ 12 \mathrm{~min}$ ) da fração livre (pico aos $\sim 45 \mathrm{~min}$ ), que foram eficientemente separadas por um intervalo mínimo de pelo menos 15 minutos. Depois de se garantir visualmente que a fração encapsulada de ácido gálico tinha sido eluída, a fração livre de ácido gálico foi recolhida em conjunto e o método da curva de calibração a $259 \mathrm{~nm}$ foi usado para determinar a concentração deste fitoquímico por espectrofotometria UV (espectrofotómetro Evolution ${ }^{\circledR}$ 300, Thermo Scientific, Hertfordshire, Inglaterra)). O mesmo método da curva de calibração foi utilizado para determinar a concentração total de ácido gálico adicionado inicialmente para produzir os transferossomas. Finalmente, a LC foi calculada da seguinte forma:

$$
L C=\frac{C_{T}-C_{N L F}}{C_{L}}
$$

Eq. 1

onde $\mathrm{C}_{\mathrm{T}}$ representa a concentração total de ácido gálico adicionada, $\mathrm{C}_{\mathrm{NLF}}$ a concentração não-encapsulada de ácido gálico e $\mathrm{C}_{\mathrm{L}}$ a concentração total de lípido, calculada a partir da quantidade pesada para produzir os transferossomas.

\section{Resultados}

A otimização da formulação transferossomal para encapsular ácido gálico foi baseada num desenho fatorial do tipo Box-Behnken (BBD) de 15 séries, três fatores e três níveis. Foram sugeridas quinze formulações pelo software STATISTICA de acordo com os níveis escolhidos para as variáveis independentes (Tabela 1). É importante ressaltar que as variáveis independentes foram escolhidas com base em dados anteriores reportados na literatura $(4,5)$, particularmente quanto aos níveis de lípido (lecitina de soja) e ativador de 
Table 1 - Independent and dependent variables of the Box-Behnken factorial design and the corresponding tested levels and defined desirable criteria (respectively).

Tabela 1 - Variáveis independentes e dependentes do desenho fatorial Box-Behnken com indicação dos níveis testados e dos critérios desejáveis definidos (respetivamente).

\begin{tabular}{lccc}
\hline & & \multicolumn{2}{c}{ Levels / Níveis } \\
Independent variables / Variáveis independentes & $\mathbf{- 1}$ & $\mathbf{0}$ & $\mathbf{1}$ \\
\hline $\mathrm{X}_{1}=$ Lipid concentration (\% w/v) / concentração de lípido (\% m/v) & 1 & 1.5 & 2 \\
$\mathrm{X}_{2}=$ EA/lipid ratio (w/w) / razão EA/lípido (m/m) & $5: 95$ & $10: 90$ & $15: 85$ \\
$\mathrm{X}_{3}=$ Sonication time (min) / tempo de sonicação (min) & 5 & Desirability / Desejabilidade & 15 \\
\hline & High / Elevada & Medium / Média & Low / Baixa \\
Dependent variables / Variáveis dependentes & 100 & 110 & 125 \\
$\mathrm{Y}_{1}=$ Size (nm) / tamanho (nm) & 0.1 & 0.2 & 0.3 \\
$\mathrm{Y}_{2}=$ PDI (polydispersity índex / índice de polidispersão) & 1 & 0.50 & 0.35 \\
$\mathrm{Y}_{3}=$ LC (loading capacity / capacidade de carga) & & \\
\hline
\end{tabular}

produce transfersomes in the last decades (2). On the other hand, the levels of sonication time were selected according to preliminary data showing that 5 to $15 \mathrm{~min}$ of sonication were sufficient to obtain vesicles with the desirable specifications (around $100 \mathrm{~nm}$ size and 0.2 PDI). The fifteen formulations were then produced and characterized in terms of the selected responses of size, PDI and LC. The results obtained are detailed in Table 2. The responses varied between $92 \mathrm{~nm}$ and 123 $\mathrm{nm}$ for size $\left(\mathrm{X}_{1}\right) ; 0.13$ and 0.28 for PDI $\left(\mathrm{X}_{2}\right)$; and 0.35 and 0.77 for $\mathrm{LC}\left(\mathrm{X}_{3}\right)$, indicating that the levels chosen for the factors were appropriate to obtain the desirable responses.

Among the three fitting models available (no interaction, two-way interactions (linear-linear) and two-way interactions (linear x quadratic), the model which best fit to correlate the experimental results and the predicted values was selected based on the obtained $\mathrm{R}^{2}$ values. The two-way interactions (linear $\mathrm{x}$ quadratic) model was chosen to perform the regression analysis, considering a 95\% confidence level, as it yielded the highest $\mathrm{R}^{2}$ values considering the three responses analyzed $\left(0.7475\right.$ for size $\left(\mathrm{Y}_{1}\right) ; 0.9949$ for PDI $\left(\mathrm{Y}_{2}\right)$ and 0.9874 for $\mathrm{LD}\left(\mathrm{Y}_{3}\right)$ ). According to the $\mathrm{R}^{2}$ values obtained, a reasonably good correlation between experimental and theoretical values was obtained, showing that the complexity of the factors-induced effects on responses justifies the necessity of using a cubic model for fitting the experimental data and predicting the desired formulation.

The coefficients and $p$-values obtained with the performed regression analyses are presented in Table 3. No significant effects (linear or quadratic) of any independent variable were observed for size $\left(\mathrm{Y}_{1}\right)$, in superfície (Tween ${ }^{\circledR} 80$ ) escolhidos, sendo que estes têm sido amplamente usados para produzir transferossomas nas últimas décadas (2). Por outro lado, os níveis de tempo de sonicação foram selecionados de acordo com dados preliminares obtidos que indicaram que 5 a $15 \mathrm{~min}$ de sonicação eram suficientes para se obter vesículas com as especificações desejáveis (cerca de $100 \mathrm{~nm}$ de tamanho e 0,2 PDI). As quinze formulações foram então produzidas e caraterizadas quanto às respostas selecionadas de tamanho, PDI e LC. Os resultados obtidos estão detalhados na Tabela 2. As respostas variaram entre $92 \mathrm{~nm}$ e $123 \mathrm{~nm}$ para o tamanho $\left(\mathrm{X}_{1}\right)$; 0,13 e 0,28 para o PDI $\left(\mathrm{X}_{2}\right)$; e 0,35 e 0,77 para a LC $\left(\mathrm{X}_{3}\right)$, mostrando que os níveis escolhidos para os fatores foram adequados para obter as respostas desejáveis.

Entre os três modelos de ajuste disponíveis (sem interação, interações bidirecionais (linear-linear) e interações bidirecionais (linear x quadrática), o modelo que apresentou o melhor ajuste para correlacionar os resultados experimentais e os valores previstos foi selecionado com base nos valores de $\mathrm{R}^{2}$ obtidos. O modelo de interações bidirecionais (linear x quadrático) foi selecionado para realizar a análise de regressão considerando um nível de confiança de $95 \%$, pois foi este modelo de ajuste que originou os valores de $\mathrm{R}^{2}$ superiores para as três respostas analisadas $(0,7475$ para tamanho $\left(\mathrm{Y}_{1}\right) ; 0,9949$ para $\mathrm{PDI}\left(\mathrm{Y}_{2}\right)$ e 0,9874 para LD $\left(\mathrm{Y}_{3}\right)$ ). De acordo com os valores de $\mathrm{R}^{2}$ obtidos, verificou-se uma correlação razoavelmente boa entre os valores experimentais e teóricos, mostrando que a complexidade dos efeitos induzidos pelos fatores nas respostas justifica a necessidade de utilizar um modelo cúbico para ajustar os dados experimentais e prever a formulação desejável. 
Table 2 - Detailed description of the formulations produced for Box-Behnken factorial design for gallic acid and the corresponding physicochemical characterization of the formulations.

Tabela 2 - Descrição detalhada das formulações produzidas de acordo com o desenho fatorial Box-Behnken e a correspondente caracterização físico-química das formulações.

\begin{tabular}{ccccccc}
\hline Sample / & \multicolumn{3}{c}{ Factors / Fatores } & \multicolumn{3}{c}{ Responses / Respostas } \\
Amostra & $\mathbf{X}_{\mathbf{1}}$ & $\mathbf{X}_{\mathbf{2}}$ & $\mathbf{X}_{\mathbf{3}}$ & $\mathbf{Y}_{\mathbf{1}}$ & $\mathbf{Y}_{\mathbf{2}}$ & $\mathbf{Y}_{\mathbf{3}}$ \\
\hline 1 & 1 & 5 & 10 & 112 & 0.28 & 0.76 \\
2 & 2 & 5 & 10 & 112 & 0.14 & 0.35 \\
3 & 1 & 15 & 10 & 92 & 0.13 & 0.71 \\
4 & 2 & 15 & 10 & 112 & 0.20 & 0.41 \\
5 & 1 & 10 & 5 & 119 & 0.24 & 0.77 \\
6 & 2 & 10 & 5 & 120 & 0.26 & 0.41 \\
7 & 1 & 10 & 15 & 120 & 0.22 & 0.76 \\
8 & 2 & 10 & 15 & 117 & 0.20 & 0.39 \\
9 & 1.5 & 5 & 5 & 111 & 0.21 & 0.49 \\
10 & 1.5 & 15 & 5 & 123 & 0.28 & 0.50 \\
11 & 1.5 & 5 & 15 & 106 & 0.14 & 0.47 \\
12 & 1.5 & 15 & 15 & 107 & 0.26 & 0.50 \\
13 & 1.5 & 10 & 10 & 115 & 0.15 & 0.55 \\
14 & 1.5 & 10 & 10 & 98 & 0.17 & 0.48 \\
15 & 1.5 & 10 & 10 & 120 & 0.15 & 0.55 \\
\hline
\end{tabular}

$\mathrm{X}_{1}$, lipid concentration $(\% \mathrm{w} / \mathrm{v}) ; \mathrm{X}_{2}, \mathrm{EA} /$ lipid ratio $(\mathrm{w} / \mathrm{w}) ; \mathrm{X}_{3}$, tempo de sonicação (min);

$\mathrm{Y}_{1}$, size $(\mathrm{nm}) ; \mathrm{Y}_{2}$, polydispersity index; $\mathrm{Y}_{3}$, loading capacity (\%)

$\mathrm{X}_{1}$, concentração de lípido $(\% \mathrm{~m} / \mathrm{v}) ; \mathrm{X}_{2}$, razão EA/lípido $(\mathrm{m} / \mathrm{m}) ; \mathrm{X}_{3}$, tempo de sonicação (min);

$\mathrm{Y}_{1}$, tamanho $(\mathrm{nm}) ; \mathrm{Y}_{2}$, índice de polidispersão; $\mathrm{Y}_{3}$, capacidade de carga (\%)

Table 3 - Regression analyses for the selected responses $\left(\mathrm{Y}_{1}, \mathrm{Y}_{2}\right.$, and $\left.\mathrm{Y}_{3}\right)$ using the two-way interaction model (linear $\mathrm{x}$ quadratic) considering the effects of the selected factors $\left(\mathrm{X}_{1}, \mathrm{X}_{2}\right.$, and $\left.\mathrm{X}_{3}\right)$. Statistically significant parameters are highlighted in bold $(\mathrm{p}<0.05)$.

Tabela 3 - Análises de regressão para as respostas selecionadas $\left(\mathrm{Y}_{1}, \mathrm{Y}_{2}\right.$, e $\left.\mathrm{Y}_{3}\right)$ com base no modelo de interação bidirecional (linear x quadrático) considerando os efeitos dos fatores selecionados $\left(\mathrm{X}_{1}, \mathrm{X}_{2}\right.$, e $\left.\mathrm{X}_{3}\right)$. Os parâmetros estatisticamente significativos estão realçados a negrito $(\mathrm{p}<0,05)$.

\begin{tabular}{|c|c|c|c|c|c|c|}
\hline \multirow{2}{*}{$\begin{array}{c}\text { Factor / } \\
\text { Fator }\end{array}$} & \multicolumn{2}{|c|}{$\mathbf{Y}_{1}$} & \multicolumn{2}{|c|}{$Y_{2}$} & \multicolumn{2}{|c|}{$Y_{3}$} \\
\hline & Coef. & $p$ & Coef. & $p$ & Coef. & $p$ \\
\hline Intercept & 112.494 & 0.001 & 0.214 & 0.000 & 0.544 & 0.001 \\
\hline $\mathrm{X}_{1}$ & 3.217 & 0.529 & -0.014 & 0.065 & -0.179 & 0.008 \\
\hline $\mathrm{X}_{1}^{2}$ & -0.883 & 0.795 & -0.011 & 0.054 & -0.030 & 0.113 \\
\hline $\mathrm{X}_{2}$ & -2.236 & 0.652 & -0.002 & 0.673 & 0.004 & 0.823 \\
\hline$X_{2}^{2}$ & 2.754 & 0.452 & -0.007 & 0.127 & 0.015 & 0.315 \\
\hline$X_{3}$ & -2.025 & 0.681 & -0.021 & 0.030 & -0.007 & 0.683 \\
\hline $\mathrm{X}_{3}^{2}$ & -3.167 & 0.399 & -0.027 & 0.009 & 0.003 & 0.791 \\
\hline $\mathrm{X}_{1} \mathrm{X}_{2}$ & 4.792 & 0.490 & 0.051 & 0.010 & 0.025 & 0.356 \\
\hline $\mathrm{X}_{1} \mathrm{X}_{2}^{2}$ & -2.937 & 0.543 & 0.009 & 0.120 & -0.004 & 0.828 \\
\hline $\mathrm{X}_{1}^{2} \mathrm{X}_{2}$ & 4.183 & 0.409 & 0.034 & 0.011 & 0.004 & 0.807 \\
\hline $\mathrm{X}_{1} \mathrm{X}_{3}$ & -0.950 & 0.883 & -0.011 & 0.168 & -0.003 & 0.917 \\
\hline $\mathrm{X}_{1}^{2} \mathrm{X}_{3}$ & -2.313 & 0.625 & -0.001 & 0.729 & 0.002 & 0.891 \\
\hline $\mathrm{X}_{2} \mathrm{X}_{3}$ & -2.558 & 0.698 & 0.013 & 0.131 & 0.004 & 0.863 \\
\hline
\end{tabular}

$\mathrm{X}_{1}$, lipid concentration $(\% \mathrm{w} / \mathrm{v}) ; \mathrm{X}_{2}$, EA/lipid ratio $(\mathrm{w} / \mathrm{w}) ; \mathrm{X}_{3}$, sonication time (min);

$\mathrm{Y}_{1}$, size (nm); $\mathrm{Y}_{2}$, polydispersity index; $\mathrm{Y}_{3}$, loading capacity (\%); Coef, coefficient; $\mathrm{p}, \mathrm{p}$-value.

$\mathrm{X}_{1}$, concentração de lípido $(\% \mathrm{~m} / \mathrm{v}) ; \mathrm{X}_{2}$, razão EA/lípido $(\mathrm{m} / \mathrm{m}) ; \mathrm{X}_{3}$, tempo de sonicação $(\mathrm{min})$;

$\mathrm{Y}_{1}$, tamanho (nm); $\mathrm{Y}_{2}$, índice de polidispersão; $\mathrm{Y}_{3}$, capacidade de carga (\%); Coef, coeficiente; p, valor-p. 
line with the small variation obtained for this parameter with all 15 formulations $(92-123 \mathrm{~nm})$. In contrast, a significant, negative, linear and quadratic effect of the sonication time $\left(\mathrm{X}_{3}\right)$ was observed for PDI $\left(\mathrm{Y}_{2}\right)$, meaning that an increase in the level of the sonication time leads to a decrease in the value of PDI (antagonistic effect). On the other hand, the interaction effects of lipid concentration $\left(\mathrm{X}_{1}\right)$ and EA:lipid ratio $\left(\mathrm{X}_{2}\right)$, in a linear $\left(\mathrm{X}_{1} \mathrm{X}_{2}\right)$ and quadratic manner $\left(\mathrm{X}_{1}{ }^{2} \mathrm{X}_{2}\right)$, were significant and synergistic for PDI $\left(\mathrm{Y}_{2}\right)$, meaning that an increase in $X_{1} X_{2}$ or $X_{1}^{2} X_{2}$ values leads to an increase in the value of PDI. Finally, the loading capacity $\left(\mathrm{Y}_{3}\right)$ was significantly and negatively affected by the lipid concentration $\left(\mathrm{X}_{1}\right)$, showing that a decrease in the lipid concentration increases the loading capacity of the produced transfersomes.

From the regression analyses, the corresponding response surface analyses in three dimensions were determined to show the relationship and interaction effects of two factors on each response, by maintaining the third factor constant at level 0 . These representations provide a more clear visualization of the effect of multifactorial variations on each dependent variable (Figure 1). The lowest values of size $\left(\mathrm{Y}_{1}\right)$ and PDI $\left(\mathrm{Y}_{2}\right)$ were predicted to be obtained for values greater than 14:96 of EA:lipid ratio $\left(\mathrm{X}_{2}\right)$ when low lipid concentrations $\left(\mathrm{X}_{1}\right)$ are used and for $1.4-1.8 \%(\mathrm{w} / \mathrm{v})$ of lipid concentration $\left(\mathrm{X}_{1}\right)$ when the sonication time $\left(\mathrm{X}_{3}\right)$ is around $10 \mathrm{~min}$. Regarding the loading capacity $\left(\mathrm{Y}_{3}\right)$, the highest values were predicted to be obtained with the lowest lipid concentration $\left(\mathrm{X}_{1}\right)$, and no significant effects of the EA:lipid ratio $\left(\mathrm{X}_{2}\right)$ or the sonication time $\left(\mathrm{X}_{3}\right)$ were observed in the response surface analyses.

From the results of the regression analyses and response surface analyses, the STATISTICA software

Table 4 - Optimum levels of the selected factors for the optimized formulation and experimental and theoretical values obtained for the selected responses.

Tabela 4 - Níveis ótimos dos fatores selecionados para obtenção da formulação otimizada e dados experimentais e teóricos obtidos quanto às respostas selecionadas.

\begin{tabular}{cccccc}
\hline $\begin{array}{c}\text { Optimized } \\
\text { formulation / } \\
\begin{array}{c}\text { Formulação } \\
\text { otimizada }\end{array}\end{array}$ & $\begin{array}{c}\text { Response / } \\
\text { Resposta }\end{array}$ & $\begin{array}{c}\text { Experimental data / } \\
\text { Dados experimentais }\end{array}$ & $\begin{array}{c}\text { Theoretical data } \\
\text { / Dados teóricos }\end{array}$ & $\begin{array}{c}\mathbf{- 9 5 \%} \\
\text { CI }\end{array}$ & $\begin{array}{c}+\mathbf{9 5 \%} \\
\text { CI }\end{array}$ \\
\hline $1: 15 / 85: 10$ & $\mathrm{Y}_{1}$ & $107 \pm 9$ & 92.0 & 42.8 & 141.2 \\
$\left(\mathrm{X}_{1}: \mathrm{X}_{2}: \mathrm{X}_{3}\right)$ & $\mathrm{Y}_{2}$ & $0.20 \pm 0.04$ & 0.13 & 0.09 & 0.18 \\
& $\mathrm{Y}_{3}$ & $0.732 \pm 0.002$ & 0.71 & 0.53 & 0.89 \\
\hline
\end{tabular}

$\mathrm{X}_{1}$, lipid concentration $(\% \mathrm{w} / \mathrm{v}) ; \mathrm{X}_{2}, \mathrm{EA} /$ lipid ratio $(\mathrm{w} / \mathrm{w}) ; \mathrm{X}_{3}$, sonication time;

$\mathrm{Y}_{1}$, size; $\mathrm{Y}_{2}$, polydispersity index; $\mathrm{Y}_{3}$, loading capacity; CI, confidence interval

$\mathrm{X}_{1}$, concentração de lípido $(\% \mathrm{~m} / \mathrm{v}) ; \mathrm{X}_{2}$, razão EA/lípido $(\mathrm{m} / \mathrm{m}) ; \mathrm{X}_{3}$, tempo de sonicação (min);

$\mathrm{Y}_{1}$, tamanho (nm); $\mathrm{Y}_{2}$, índice de polidispersão; $\mathrm{Y}_{3}$, capacidade de carga (\%); CI, intervalo de confiança. 

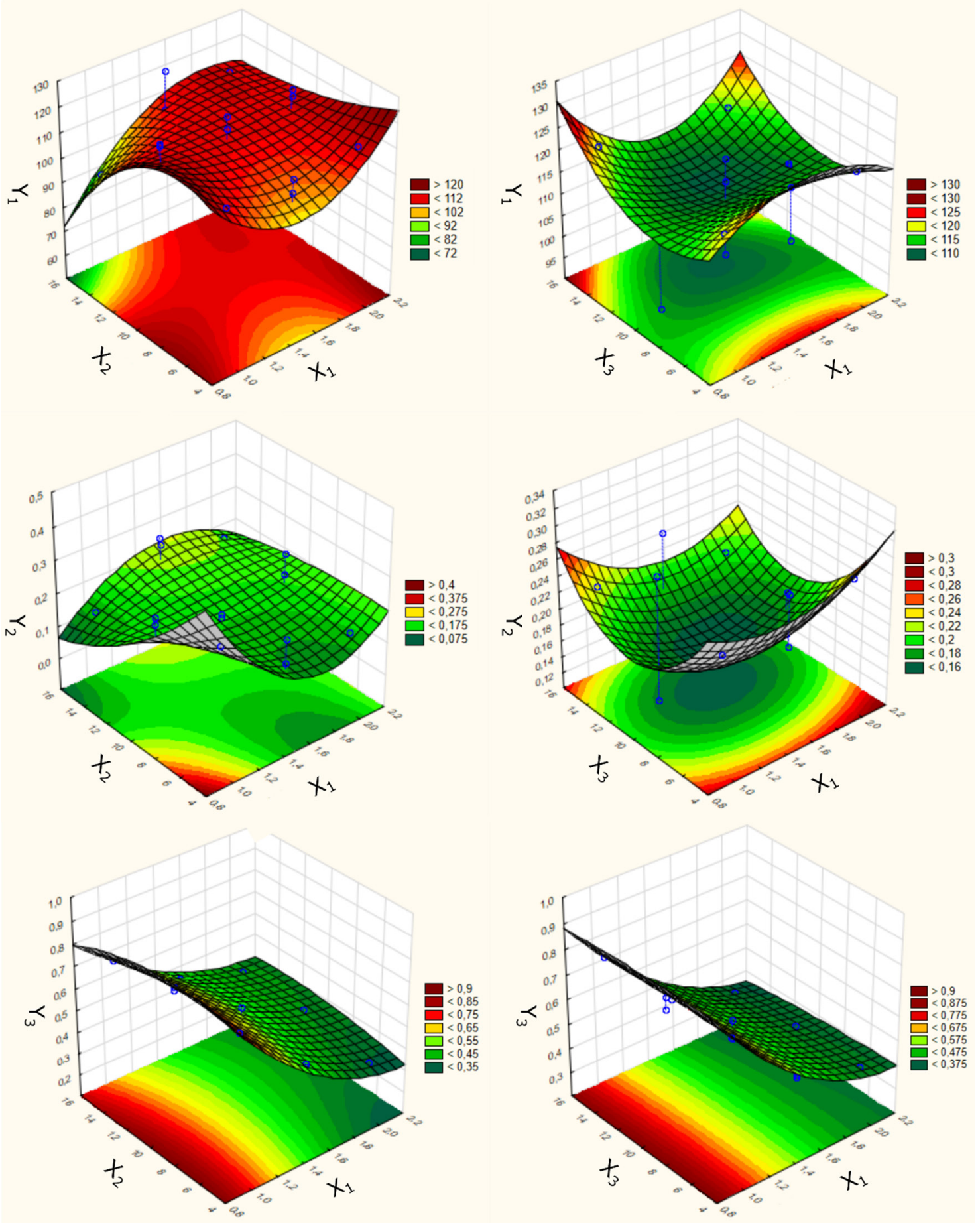

Figure 1 - Response surface plots in three dimensions for each dependent variable according to the response degree (light green - lowest response level and dark red - highest response level). $\mathrm{X}_{1}$, lipid concentration $(\% \mathrm{w} / \mathrm{v}) ; \mathrm{X}_{2}$, EA/lipid ratio $(\mathrm{w} / \mathrm{w}) ; \mathrm{X}_{3}$, sonication time; $\mathrm{Y}_{1}$, size; $\mathrm{Y}_{2}$, polydispersity index; $Y_{3}$, loading capacity.

Figura 1 - Gráficos de superfície de resposta em três dimensões para cada variável dependente em função do nível de resposta (verde claro - nível de resposta mais baixo e vermelho escuro - nível de resposta mais elevado). $X_{1}$, concentração de lípido (\% m/v); $X_{2}$, razão EA/lípido $(\mathrm{m} / \mathrm{m}) ; X_{3}$, tempo de sonicação (min); $\mathrm{Y}_{1}$, tamanho (nm); $\mathrm{Y}_{2}$, índice de polidispersão; $\mathrm{Y}_{3}$, capacidade de carga (\%). 
calculated the optimum values of the factors to produce the desirable formulation in terms of the selected responses (Table 4). To validate the optimization procedure and the prediction ability of the theoretical model, three independent replicates of the optimized formulation were produced and characterized (Table 4). The experimental results were in good agreement with the theoretical prediction, validating the use of this experimental design for the optimization of gallic acidloaded transfersomes.

\section{Discussion}

In this work, a gallic acid-loaded transfersomal formulation was optimized through a quality-by-design approach, namely BBD. This strategy was found to be an efficient, time- and reagent-saving way of optimizing nanodelivery systems, as previously reported $(4,20$ 23 ), in terms of size, PDI, and LC. Concerning vesicle size, all produced formulations yielded similar results with hydrodynamic diameters around $100 \mathrm{~nm}$. In fact, increasing evidence suggests that transfersomes smaller than $300 \mathrm{~nm}$ are suitable to penetrate the stratum corneum after cutaneous applications (2). Moreover, it was previously reported that the lower the vesicle size, the greater their skin penetration (24), one justification for the optimization of the formulations to minimize the vesicle size. Among other transfersomal formulations optimized by BBD, the vesicular system optimized herein presented a smaller PDI value than the apigeninloaded transfersomal formulation prepared by a similar method (4), showing a better homogeneity of size distribution. Moreover, the encapsulation efficiency of the optimized formulation, herein presented as LC, was superior to that reported for apigenin, sodium stibogluconate, and raloxifene hydrochloride in other transfersomal systems $(4,22,23)$. Altogether, these data suggest that this experimental design was successfully implemented to optimize the gallic acid-loaded vesicular system.

To our knowledge, this is the first report of the development of a transfersomal formulation for the transdermal delivery of gallic acid. Nonetheless, various nanotechnological approaches have been explored for the nanodelivery of this phytochemical to overcome its bioavailability issues. For example, gallic acid has been encapsulated in polymeric nanoparticles $(14,16,25)$, reverse micelles (26), and dendrimers (27). However, considering the cutaneous administration of gallic acid, vesicular systems have been more extensively studied with the development of various liposomal, niosomal, obtidos com a menor concentração lipídica $\left(X_{1}\right)$, sem se verificar efeitos significativos da razão EA:lípido $\left(\mathrm{X}_{2}\right)$ ou do tempo de sonicação $\left(\mathrm{X}_{3}\right)$ na análise de superfície de resposta.

A partir dos resultados das análises de regressão e de superfície de resposta, o software STATISTICA calculou os valores ótimos dos fatores para produzir a formulação desejável em termos das respostas selecionadas (Tabela 4). Para validar o procedimento de otimização e a capacidade de predição deste modelo teórico, foram produzidas e caraterizadas três réplicas independentes da formulação otimizada (Tabela 4). Os resultados experimentais foram concordantes com a previsão teórica, validando o uso deste desenho experimental para a otimização de transferossomas para a veiculação de ácido gálico.

\section{Discussão}

Neste trabalho, uma formulação transferossomal para veicular ácido gálico foi otimizada através de uma abordagem de quality-by-design, a saber BBD. Verificou-se que esta estratégia é efetivamente uma estratégia eficiente e económica de otimizar nanossistemas de veiculação, conforme reportado anteriormente $(4,20-23)$, em termos de tamanho, PDI e LC. Em relação ao tamanho das vesículas, todas as formulações produzidas apresentaram resultados semelhantes com diâmetros hidrodinâmicos em torno de $100 \mathrm{~nm}$. De facto, evidências crescentes sugerem que transferossomas menores que $300 \mathrm{~nm}$ são adequados para penetrar no estrato córneo após aplicações cutâneas (2). Além disso, foi anteriormente reportado que quanto menor o tamanho da vesícula, maior sua penetração na pele (24), motivo pelo qual as formulações foram otimizadas para minimizar o tamanho da vesícula. Entre outras formulações transferossomais otimizadas por BBD, o sistema vesicular otimizado neste trabalho apresentou um valor de PDI menor que uma formulação transferossomal desenvolvida para veicular a apigenina e preparada por um método semelhante (4), demostrando uma melhor homogeneidade da distribuição de tamanho. Além disso, a eficiência de encapsulação da formulação otimizada, aqui apresentada como LC, foi superior à relatada para a apigenina, o estibogluconato de sódio e cloridrato de raloxifeno noutros sistemas transferossomais $(4,22$, 23). Em suma, esses dados sugerem que este desenho experimental foi implementado com sucesso para otimizar o sistema vesicular para encapsular o ácido gálico. 
and glycerosomal formulations (17,28-32). Since transfersomes display better skin penetration properties than liposomes and niosomes, as well as an improved shelf-life (2), it is expected that the formulation optimized herein will be more advantageous in terms of efficacy and stability than the others developed so far. Further studies are awaited to further characterize the physicochemical properties of the gallic acid-loaded transfersomes, as well as their antioxidant efficacy, skin permeation efficiency, and cellular toxicity using in vitro approaches.

\section{Conclusion}

The successful optimization of an innovative gallic acid-loaded transfersomal formulation for transdermal delivery is reported herein. Moreover, BBD was shown to be an efficient experimental design to optimize vesicular systems for the gallic acid delivery. This study opens up the possibility of making use of the pleiotropic properties of gallic acid for the prophylaxis and treatment of cutaneous conditions by efficiently achieving a transdermal delivery. Following the preliminary data presented herein, further investigations are awaited to confirm the efficacy, safety, and stability of the optimized transfersomal formulation.

\section{Authors Contributions Statement}

CPL, conceptualization and study design; CPL and $\mathrm{CV}$, experimental implementation; $\mathrm{CPL}$ and $\mathrm{CV}$, data analysis; CPL, drafting, editing and reviewing; CPL, figures and graphics; CPL, supervision and final writing.
Segundo temos conhecimento, este é o primeiro trabalho reportadoquanto ao desenvolvimento de uma formulação transferossomal para a veiculação transdérmica de ácido gálico. No entanto, várias abordagens nanotecnológicas têm vindo a ser exploradas para a nanoformulação desse fitoquímico, a fim de superar os seus problemas de biodisponibilidade. Por exemplo, o ácido gálico foi encapsulado em nanopartículas poliméricas (14, $16,25)$, micelas reversas (26) e dendrímeros (27). No entanto, considerando a administração cutânea de ácido gálico, os sistemas vesiculares têm sido estudados mais extensivamente com o desenvolvimento de várias formulações lipossomais, niossomais e glicerossomais (17, 28-32). Como os transferossomas exibem melhores propriedades de penetração na pele do que os lipossomas e os niossomas, bem como uma estabilidade coloidal superior (2), espera-se que a formulação otimizada neste trabalho seja mais vantajosa em termos de eficácia e estabilidade do que as outras desenvolvidas até ao momento. Estudos adicionais serão necessários para caraterizar outras propriedades físico-químicas destes transferossomas, bem como a sua eficácia antioxidante, a sua eficiência quanto à permeação cutânea e a sua toxicidade celular usando abordagens in vitro.

\section{Conclusões}

Neste trabalho, a otimização de uma formulação transferossomal inovadora de ácido gálico para veiculação transdérmica foi realizada com sucesso. Além disso, o BBD demonstrou ser um desenho experimental eficiente para otimizar sistemas vesiculares para a administração de ácido gálico. Este estudo abre caminho quanto à possibilidade de aproveitar as ações pleiotrópicas do ácido gálico na profilaxia e no tratamento de doenças cutâneas, pela eventual melhoria da sua veiculação transdérmica. Após os dados preliminares aqui apresentados, investigações adicionais serão necessárias para confirmar a eficácia, a segurança e a estabilidade desta formulação transferossomal de ácido gálico.

\section{Declaração sobre as contribuições do autor}

CPL, conceção e desenho do estudo; CPL e CV, implementação experimental; $\mathrm{CPL}$ e $\mathrm{CV}$, análise de dados; CPL, redação, edição e revisão; CPL, figuras e gráficos; CPL, supervisão e redação final. 


\section{Funding}

This work was funded by national funds through FCT - Foundation for Science and Technology, I.P., under the UIDB/04567/2020 and UIDP/ 04567/2020 projects.

\section{Conflict of Interests}

The authors declare there are no financial and/or personal relationships that could present a potential conflict of interests.

\section{Financiamento}

Este trabalho foi financiado pela Fundação para a Ciência e a Tecnologia (FCT) através dos projetos UIDP/04567/2020 e UIDB/04567/2020.

\section{Conflito de Interesses}

Os autores declaram que não há relações financeiras e/ou pessoais que possam representar um potencial conflito de interesses. 


\section{References / Referências}

1. Kapoor B, Gupta R, Gulati M, Singh SK, Khursheed R, Gupta M. (2019) The Why, Where, Who, How, and What of the vesicular delivery systems. Adv Colloid Interface Sci 271:101985-2002. https://doi.org/10.1016/j.cis.2019.07.006.

2. Fernández-García R, Lalatsa A, Statts L, Bolás-Fernández F, Ballesteros MP, Serrano DR.(2020) Transferosomes as nanocarriers for drugs across the skin: Quality by design from lab to industrial scale. Int J Pharm 573:118817-31. https://doi.org/10.1016/j.ijpharm.2019.118817.

3. Natsheh H, Touitou E. (2020) Phospholipid Vesicles for Dermal/Transdermal and Nasal Administration of Active Molecules: The Effect of Surfactants and Alcohols on the Fluidity of Their Lipid Bilayers and Penetration Enhancement Properties. Molecules 25(13):2959-3000. https://doi. $\operatorname{org} / 10.3390 /$ molecules25132959.

4. Jangdey MS, Gupta A, Saraf S, Saraf S. (2017) Development and optimization of apigenin-loaded transfersomal system for skin cancer delivery: in vitro evaluation. Artif Cells, Nanomed, Biotechnol 45(7):1452-62. https://doi.org/10.1080/21691401.2016.1247850.

5. Ahmed TA. (2015) Preparation of transfersomes encapsulating sildenafil aimed for transdermal drug delivery: Plackett-Burman design and characterization. J Liposome Res 25(1):1-10. https://doi.org/10.3109/08982104.2014.950276.

6. Al Shuwaili AH, Rasool BK, Abdulrasool AA. (2016) Optimization of elastic transfersomes formulations for transdermal delivery of pentoxifylline. Eur J Pharm Biopharm 102:101-14. https://doi.org/10.1016/j.ejpb.2016.02.013.

7. Kateh Shamshiri M, Momtazi-Borojeni AA, Khodabandeh Shahraky M, Rahimi F. (2019) Lecithin soybean phospholipid nano-transfersomes as potential carriers for transdermal delivery of the human growth hormone. J Cell Biochem 120(6):9023-33. https://doi.org/10.1002/jcb.28176.

8. EMA. Diractin: Withdrawal of the marketing authorisation application 2008 [cited 2020 july 18 th]. Available from: https://www.ema.europa.eu/ en/medicines/human/withdrawn-applications/diractin.

9. Adam S, Suzzi D, Radeke C, Khinast JG. (2011) An integrated Quality by Design (QbD) approach towards design space definition of a blending unit operation by Discrete Element Method (DEM) simulation. Eur J Pharm Sci 42(1-2):106-15. https://doi.org/10.1016/j.ejps.2010.10.013.

10. Kahkeshani N, Farzaei F, Fotouhi M, Alavi SS, Bahramsoltani R, Naseri R, et al. (2018) Pharmacological effects of gallic acid in health and diseases: A mechanistic review. Iran J Basic Med Sci 22(3):225-37. https://doi.org/10.22038/ijbms.2019.32806.7897.

11. Choubey S, Goyal S, Varughese LR, Kumar V, Sharma AK, Beniwal V. (2018) Probing Gallic Acid for Its Broad Spectrum Applications. Mini Rev Med Chem 18(15):1283-93. https://doi.org/10.2174/1389557518666180330114010.

12. Khan BA, Mahmood T, Menaa F, Shahzad Y, Yousaf AM, Hussain T, et al. (2018) New Perspectives on the Efficacy of Gallic Acid in Cosmetics \& Nanocosmeceuticals. Curr Pharm Des 24(43):5181-7. https://doi.org/10.2174/1381612825666190118150614.

13. Cai Y, Zhang J, Chen NG, Shi Z, Qiu J, He C, et al. (2017) Recent Advances in Anticancer Activities and Drug Delivery Systems of Tannins. Med Res Rev 37(4):665-701. https://doi.org/10.1002/med.21422.

14. de Cristo Soares Alves A, Mainardes RM, Khalil NM. (2016) Nanoencapsulation of gallic acid and evaluation of its cytotoxicity and antioxidant activity. Mater Sci Eng C Mater Biol Appl 60:126-34. https://doi.org/10.1016/j.msec.2015.11.014.

15. Shah ST, W AY, Saad O, Simarani K, Chowdhury Z, A AA, et al. (2017) Surface Functionalization of Iron Oxide Nanoparticles with Gallic Acid as Potential Antioxidant and Antimicrobial Agents. Nanomaterials (Basel) 7(10). https://doi.org/10.3390/nano7100306.

16. Tapia-Hernández JA, Del-Toro-Sánchez CL, Cinco-Moroyoqui FJ, Ruiz-Cruz S, Juárez J, Castro-Enríquez DD, et al. (2019) Gallic Acid-Loaded Zein Nanoparticles by Electrospraying Process. J Food Sci 84(4):818-31. https://doi.org/10.1111/1750-3841.14486.

17. Zhang Y, Pu C, Tang W, Wang S, Sun Q. (2019) Gallic acid liposomes decorated with lactoferrin: Characterization, in vitro digestion and antibacterial activity. Food Chem 293:315-22. https://doi.org/10.1016/j.foodchem.2019.04.116.

18. Ferreira SLC, Bruns RE, Ferreira HS, Matos GD, David JM, Brandão GC, et al. (2007) Box-Behnken design: An alternative for the optimization of analytical methods. Anal Chim Acta 597(2):179-86. https://doi.org/https://doi.org/10.1016/j.aca.2007.07.011.

19. Bezerra MA, Santelli RE, Oliveira EP, Villar LS, Escaleira LA. (2008) Response surface methodology (RSM) as a tool for optimization in analytical chemistry. Talanta 76(5):965-77. https://doi.org/10.1016/j.talanta.2008.05.019.

20. Lopes-de-Campos D, Pinto RM, Lima SAC, Santos T, Sarmento B, Nunes C, et al. (2019) Delivering amoxicillin at the infection site - a rational design through lipid nanoparticles. Int J Nanomedicine 14:2781-95. https://doi.org/10.2147/ijn.S193992.

21. Magalhães J, L LC, A CV, S GS, Pinheiro M, Reis S. (2020) Optimization of Rifapentine-Loaded Lipid Nanoparticles Using a Quality-by-Design Strategy. Pharmaceutics 12(1):75-87. https://doi.org/10.3390/pharmaceutics12010075.

22. Dar MJ, Din FU, Khan GM. (2018) Sodium stibogluconate loaded nano-deformable liposomes for topical treatment of leishmaniasis: macrophage as a target cell. Drug Deliv 25(1):1595-606. https://doi.org/10.1080/10717544.2018.1494222.

23. Mahmood S, Taher M, Mandal UK. (2014) Experimental design and optimization of raloxifene hydrochloride loaded nanotransfersomes for transdermal application. Int J Nanomedicine 9:4331-46. https://doi.org/10.2147/ijn.S65408.

24. Verma DD, Verma S, Blume G, Fahr A. (2003) Particle size of liposomes influences dermal delivery of substances into skin. Int J Pharm 258(12):141-51. https://doi.org/10.1016/s0378-5173(03)00183-2.

25. Nagpal K, Singh SK, Mishra DN. (2012) Nanoparticle mediated brain targeted delivery of gallic acid: in vivo behavioral and biochemical studies for improved antioxidant and antidepressant-like activity. Drug Deliv 19(8):378-91. https://doi.org/10.3109/10717544.2012.738437.

26. Chatzidaki MD, Papavasileiou KD, Papadopoulos MG, Xenakis A. (2017) Reverse Micelles As Antioxidant Carriers: An Experimental and Molecular Dynamics Study. Langmuir 33(20):5077-85. https://doi.org/10.1021/acs.langmuir.7b00213.

27. Abdou EM, Masoud MM. (2018) Gallic acid-PAMAM and gallic acid-phospholipid conjugates, physicochemical characterization and in vivo evaluation. Pharm Dev Technol 23(1):55-66. https://doi.org/10.1080/10837450.2017.1344994.

28. Chaikul P, Khat-Udomkiri N, Iangthanarat K, Manosroi J, Manosroi A. (2019) Characteristics and in vitro anti-skin aging activity of gallic acid loaded in cationic CTAB niosome. Eur J Pharm Sci 131:39-49. https://doi.org/10.1016/j.ejps.2019.02.008.

29. Caddeo C, Manca ML, Matos M, Gutierrez G, Díez-Sales O, Peris JE, et al. (2017) Functional response of novel bioprotective poloxamerstructured vesicles on inflamed skin. Nanomedicine 13(3):1127-36. https://doi.org/10.1016/j.nano.2016.12.017.

30. Manosroi A, Jantrawut P, Akihisa T, Manosroi W, Manosroi J. (2011) In vitro and in vivo skin anti-aging evaluation of gel containing niosomes loaded with a semi-purified fraction containing gallic acid from Terminalia chebula galls. Pharm Biol 49(11):1190-203. https://doi.org/10.3109/1 3880209.2011.576347.

31. Manosroi A, Jantrawut P, Akazawa H, Akihisa T, Manosroi W, Manosroi J. (2011) Transdermal absorption enhancement of gel containing elastic niosomes loaded with gallic acid from Terminalia chebula galls. Pharm Biol 49(6):553-62. https://doi.org/10.3109/13880209.2010.528432.

32. Fang JY, Hung CF, Hwang TL, Huang YL. (2005) Physicochemical characteristics and in vivo deposition of liposome-encapsulated tea catechins by topical and intratumor administrations. J Drug Target 13(1):19-27. https://doi.org/10.1080/10611860400015977. 